\title{
Protonacijske ravnoteže linearnih homopolikiselina
}

DOI: $10.15255 /$ KUI.2014.013

KUI-21/2015

Pregledni rad

Prispjelo 20. ožujka 2014.

Prihvaćeno 9. lipnja 2014.

\author{
J. Požar * \\ Prirodoslovno-matematički fakultet, Sveučilište u Zagrebu \\ Horvatovac 102a, Zagreb
}

\begin{abstract}
| Sažetak
\| Ključne riječi

Polimer, polielektrolit, homopolikiselina, protonacija, protuioni
\end{abstract}

U radu je dan sažet pregled dosadašnjih istraživanja termodinamike protonacije linearnih homopolikiselina, posebice onih visoke gustoće naboja. Pored prikaza eksperimentalnih rezultata koji se mogu naći u literaturi, u radu su opisani i teorijski modeli za obradu ovisnosti protonacijskih konstanti ravnoteže o stupnju disocijacije monomera, odnosno o ionskoj jakosti (cilindrični model temeljen na Poisson-Boltzmannovoj jednadžbi, Sternov cilindrični model, Isingov model, Högfeldtov model, Mandelov model i model Katchalskoga). Primjenjivost navedenih modela za opis protonacijske ravnoteže linearnih homopolikiselina razmatrana je s obzirom na gustoću naboja poliiona, koncentraciju dodanog elektrolita i vrstu protuiona koji kompenziraju naboj makroiona. Ukratko su prikazani i rezultati Monte Carlo simulacija protonacijske ravnoteže. Dodatno, dan je osvrt na česte pogreške vezane uz baždarenje elektrokemijskih članaka prilikom određivanja specijacije polikiselina u otopinama.

\section{Uvod}

Polielektroliti su polimerni spojevi čiji su monomeri u otopinama, odnosno u taljevinama, električki nabijeni. ${ }^{1-23}$ Najjednostavniji polielektroliti sastoje se od identičnih monomernih podjedinica koje sadržavaju funkcijske skupine (nosioce električkog naboja) povezane u lanac. Takvi spojevi poznati su i pod nazivom linearni homopolielektroliti. ${ }^{1-23}$ Ukoliko polimerni lanci sadržavaju više različitih funkcijskih skupina, polielektroliti se nazivaju heteropolielektrolitima.

Polielektroliti se mogu klasificirati kao polimerne soli, koje u otopinama disociraju na električki nabijene poliione i jednostavne protuione suprotnog naboja, ili kao polikiseline, odnosno kao polibaze. ${ }^{1-23}$ I u slučaju polikiselina i u slučaju polibaza, kao rezultat kiselinsko-bazne ravnoteže, na polimernom lancu bit će prisutan određeni broj električki nabijenih skupina. U literaturi se polikiseline i polibaze najčešće klasificiraju kao jake, odnosno kao slabe. ${ }^{1,2}$ Navedena podjela provodi se na osnovi kiselinsko-baznih svojstava monomera koji podliježu (de)protonaciji u otopinama. Tako se polielektroliti izgrađeni od monomera koji u otopinama pokazuju svojstva jakih kiselina i baza nazivaju jakim polikiselinama, odnosno polibazama. Analogno, ukoliko su monomeri u otopinama slabe kiseline, odnosno baze, i odgovarajući polielektroliti najčešće se klasificiraju kao slabe kiseline i baze.

\footnotetext{
*Dr. sc. Josip Požar

e-pošta: pozar@chem.pmf.hr
}

lako polielektroliti obuhvaćaju široku klasu spojeva, u literaturi se pod pojmom polielektrolit najčešće podrazumijeva spoj linearne strukture kod kojeg je gustoća naboja na poliionu velika, a nabijene funkcijske skupine istoimenoga naboja. ${ }^{1}$ Naime, u slučaju kada se nabijene skupine na poliionu nalaze na udaljenosti od svega nekoliko A, fizikalno-kemijska svojstva svih polielektrolita bit će slična, neovisno o njihovu kemijskom sastavu. Razlog navedenoj činjenici su iznimno nepovoljne elektrostatske interakcije između nabijenih segmenata koje se uvijek, barem djelomično, moraju kompenzirati interakcijama sa suprotno nabijenim vrstama. ${ }^{1}$ Djelomična kompenzacija odbojnih interakcija na poliionima velike gustoće naboja ostvaruje se kondenzacijom (vezivanjem) jednostavnih protuiona. ${ }^{1,4,5}$ Za razliku od otopina jednostavnih elektrolita, otopine polielektrolita spomenutog tipa stoga nikada nisu idealne. ${ }^{1,4,5}$

Pored ionske kondenzacije, najvažnije je bitno drugačije kemijsko svojstvo polielektrolita visoke gustoće naboja u odnosu na slobodne monomere od kojih su izgrađeni iznimna sklonost ka interpolielektrolitnoj neutralizaciji s poliionima suprotnog naboja. Od sredine prošloga stoljeća do danas zabilježene su reakcije zamjetnog broja takvih polielektrolita, ${ }^{3,6}$ pri čemu treba naglasiti da nabijeni monomeri od kojih su izgrađeni poliioni nisu bili skloni međusobnoj asocijaciji, niti stvaranju makromolekulskih agregata. ${ }^{7}$ Tijekom sedamdesetih $\mathrm{i}$ osamdesetih godina ispitana je i adsorpcija nekih sintetskih polielektrolita visoke gustoće naboja na čestice oksida polumetala $\left(\mathrm{SiO}_{2}\right)$ i metala $\left(\mathrm{TiO}_{2}\right.$, hematit). ${ }^{8,9}$ Kao i u slučaju interpolielektrolitne neutralizacije, zamijećeno je da se radi o nespecifičnim i izrazito povoljnim procesima. Reakcija dvaju sintetskih polielektrolita 
suprotnog naboja i mogućnost adsorpcije navedenih spojeva na suprotno nabijene koloidne čestice preduvjet su za izgradnju složenih nanokompozita postupkom sukcesivne adsorpcije makroiona na podlogu od oksida metala, odnosno polumetala. Navedenu činjenicu prvi je prepoznao G. Decher. Godine 1991. sukcesivnom adsorpcijom linearnih sintetskih polielektrolita suprotnoga naboja na pločicu od silicijeva dioksida priredio je prvi polielektrolitni višesloj. ${ }^{10} \mathrm{Od}$ tada do današnjih dana priređeni su mnogobrojni višeslojevi izgrađeni u pravilu od najmanje jednog polielektrolita visoke gustoće naboja i različitih električki nabijenih makromolekula (proteini, sintetski i prirodni poliioni različite gustoće naboja), odnosno koloidnih čestica s iznimnim fizikalno-kemijskim svojstvima. ${ }^{10-12} \mathrm{U}$ novije vrijeme polielektrolitni višeslojevi zaokupili su velik broj istraživača zbog mogućnosti njihove praktične primjene $u$ biotehnologiji ${ }^{13,14}$ i biomedicini, ${ }^{15}$ ali i industriji. ${ }^{11} \mathrm{U}$ tijeku su i istraživanja biokompatibilnosti višeslojeva ${ }^{11}$ i polielektrolitnih kapsula ${ }^{16}$ poradi mogućnosti njihove upotrebe za ciljanu dostavu manjih molekula i lijekova u tkiva zahvaćena tumorom ili nekom drugom bolesti. Primjerice, zamijećeno je da se mnoge molekule mogu ugraditi u višeslojeve iz kojih se potom postupno otpuštaju. Čak je moguća i ugradnja enzima u višeslojeve bez gubitka njihove aktivnosti. ${ }^{11,17}$ Štoviše, neki su se enzimi u višeslojevima pokazali aktivnijima nego u otopini. ${ }^{17}$ Razumljivo, istraživanja višeslojeva intenzivirala su i istraživanja interpolielektrolitne neutralizacije u otopinama, odnosno protonacijske ravnoteže polikiselina i polibaza. Međutim, za razliku od istraživanja interpolielektrolitne neutralizacije, istraživanja protonacijske ravnoteže linearnih polielektrolita velike gustoće naboja još su uvijek relativno malobrojna. ${ }^{1,2}$ Od početka pedesetih godina prošloga stoljeća do današnjih dana ispitana je protonacijska ravnoteža svega nekoliko polikiselina. Rezultati tih istraživanja provedenih na istim polielektrolitima nerijetko se poprilično razlikuju, što otežava kvantitativnu obradu eksperimentalnih podataka u slučaju reakcija u kojima sudjeluju polikiseline, poput primjerice procesa interpolielektrolitne neutralizacije. S obzirom na rastući interes za istraživanja fizikalno-kemijskih svojstava sintetskih, linearnih polielektrolita, u ovome će radu ukratko biti opisani najčešće primjenjivani pristupi obradi protonacijskih ravnoteža linearnih homopolikiselina i dosadašnji rezultati odgovarajućih istraživanja opisani u literaturi.

\section{Kvantitativna obrada protonacijske ravnoteže linearnih homopolikiselina}

Za opis protonacijske ravnoteže u vodenim otopinama homopolikiselina bit će korisno razmotriti linearni poliion čije funkcijske skupine u vodi mogu disocirati na konjugiranu bazu i $\mathrm{H}^{+}$. Neka su funkcijske skupine električki nabijene u protoniranom obliku $\left(-\mathrm{HA}^{+}\right)$, odnosno neutralne u deprotoniranom obliku (-A). Proces deprotonacije skupine na lancu tada je moguće prikazati sljedećom jednadžbom:

$$
-\mathrm{HA}^{+}(\mathrm{aq}) \rightleftharpoons-\mathrm{A}(\mathrm{aq})+\mathrm{H}^{+}(\mathrm{aq})
$$

Za navedenu reakciju može se definirati termodinamička konstanta ravnoteže deprotonacije prema izrazu: ${ }^{2}$

$$
K^{\ominus}=\frac{a_{-H A^{+}}}{a_{-A} a_{H^{+}}}
$$

u kojem je $\mathrm{s} \mathrm{a}_{\mathrm{HA}^{+}}$Označen relativni aktivitet protonirane skupine, oznakom $a_{-A}$ relativni aktivitet deprotonirane, dok je $s a_{H^{+}}$označen aktivitet vodikova iona u otopini (gotovo redovito definiran na standardnoj puferskoj skali). ${ }^{18}$ Uvođenjem koeficijenata aktiviteta $(\gamma)$ pojedinih sudionika reakcije izraz (2) moguće je zapisati na sljedeći način:1,2

$$
K^{\ominus}=\frac{\frac{\gamma_{-\mathrm{HA}^{+}}\left[-\mathrm{HA}^{+}\right]}{C^{\ominus}}}{\frac{\gamma_{-\mathrm{A}}[-\mathrm{A}]}{C^{\ominus}} \frac{\gamma_{\mathrm{H}^{+}}\left[\mathrm{H}^{+}\right]}{C^{\ominus}}}
$$

gdje je $s C^{\ominus}$ označena standardna koncentracija (najčešće $1 \mathrm{~mol} \mathrm{dm}^{-3}$ ). U slučaju kada je udaljenost između protoniranih $-\mathrm{HA}^{+}$skupina na lancu dovoljno velika, odbojne su elektrostatske interakcije između nabijenih skupina na polimernom lancu zanemarive. U tom slučaju omjer umnožaka ravnotežnih koncentracija produkata i reaktanata poprimit će konstantnu vrijednost. Ukoliko se raspodjele iona oko protona na poliionu i protona u otopini ne razlikuju, opravdano je uvođenje prosječnog koeficijenta aktiviteta nabijenih vrsta, dok se koeficijent aktiviteta nenabijene skupine može smatrati jednakim jedinici. ${ }^{19} \mathrm{Uz}$ navedene pretpostavke standardna konstanta ravnoteže deprotonacije $-\mathrm{HA}^{+}$bit će približno jednaka:

$$
K^{\ominus} \approx \frac{\left[-\mathrm{HA}^{+}\right] c^{\ominus}}{\left[\mathrm{H}^{+}\right][-\mathrm{A}]}
$$

Iz izraza (4) može se zaključiti da će za pozitivno nabijenu polikiselinu $K^{\ominus}$ iznosom biti bliska koncentracijskoj konstanti ravnoteže:

$$
K=\frac{\left[-\mathrm{HA}^{+}\right]}{\left[\mathrm{H}^{+}\right][-\mathrm{A}]}
$$

Suprotno, ako je u potpunosti protonirana polikiselina neutralna $(-\mathrm{HB})$, standardna konstanta ravnoteže bit će približno jednakog iznosa kao i koncentracijska konstanta samo pri izrazito niskim ionskim jakostima $\left(I_{c}\right)$, jer se koeficijenti aktiviteta nabijenih vrsta u izrazu za $K^{\ominus}$ nalaze u brojniku:

$$
K^{\ominus}=\frac{\frac{\gamma_{-\mathrm{B}^{-}}\left[-\mathrm{B}^{-}\right]}{C^{\ominus}} \frac{\gamma_{\mathrm{H}^{+}}\left[\mathrm{H}^{+}\right]}{C^{\ominus}}}{\frac{\gamma_{-\mathrm{HB}}[-\mathrm{HB}]}{C^{\ominus}}}
$$

Za njezino određivanje najčešće je potrebno ekstrapolirati koncentracijske konstante ravnoteže na $I_{c}=0$, ili primjenjivati neku od teorija za procjenu koeficijenata aktiviteta (najčešće Debye-Hückelov model). ${ }^{19-21}$ Valja napomenuti da koeficijenti aktiviteta $\mathrm{H}^{+}$u otopini i protona na lancu ne moraju biti nužno jednaki. Kako je već bilo govora, ras- 
podjela protuiona oko nabijene skupine na lancu ne mora biti istovjetna njihovoj raspodjeli oko $\mathrm{H}^{+} \mathrm{u}$ otopini.

U slučaju linearnih polikiselina visoke gustoće naboja koncentracijska konstanta ravnoteže deprotonacije (5) funkcija je stupnja disocijacije $(\alpha)$, zbog čega se navedene veličine najčešće nazivaju prividnim konstantama deprotonacije polikiseline $\left.\left(K_{\mathrm{ap}}\right)\right)^{2,22-24}$ Razlike između prividnih konstanti deprotonacije pri različitim $\alpha$ uglavnom su posljedica elektrostatskog odbijanja između nabijenih skupina na polielektrolitnom lancu. ${ }^{2,22-24}$ Naime, kada je potpuno protonirana polikiselina neutralna, $\mathrm{p} K_{\mathrm{ap}}$ raste s porastom gustoće naboja na lancu. Suprotno, kada je protonirana kiselina pozitivno nabijena, $\mathrm{p} K_{\mathrm{ap}}$ poprima najniže vrijednosti pri najvećoj gustoći naboja. U literaturi se također mogu naći i miješane prividne konstante ravnoteže: ${ }^{2,19,22}$

$$
K_{\mathrm{ap}}^{*}=\frac{\left[-\mathrm{HA}^{+}\right]}{\mathrm{a}_{\mathrm{H}^{+}}[-\mathrm{A}]}
$$

Konstanta ravnoteže deprotonacije monomera koja opisuje proces disocijacije kada nema nepovoljnih međudjelovanja na poliionu naziva se intrinzičkom konstantom deprotonacije, ${ }^{2,22-24}$ koja može biti termodinamička $\left(K_{\text {in }}{ }^{\ominus}\right.$, koncentracijska $\left(K_{\text {in }}\right)$, ili miješana $\left(K_{\text {in }}{ }^{*}\right)$. Koncentracijsku i miješanu intrinzičku konstantu moguće je odrediti ekstrapolacijom eksperimentalno određenih $\mathrm{p} K_{\mathrm{ap}}\left(\right.$ odnosno $\left.\mathrm{p} K_{\mathrm{ap}}{ }^{*}\right)$ na $\alpha \longrightarrow 0$, u slučaju kada je konjugirana baza funkcijske skupine negativno nabijena, odnosno na $\alpha \rightarrow 1$ kada je konjugirana baza neutralna. Za određivanje standardne intrinzičke konstante valja ekstrapolirati prividne, koncentracijske konstante ravnoteže na nultu ionsku jakost.

Dakako, razlike intrinzičkih i prividnih vrijednosti $\mathrm{p} K$ nisu isključivo posljedica nepovoljnih elektrostatskih interakcija između nabijenih skupina. Naime, povećanje gustoće naboja na poliionu zbog deprotonacije (ili protonacije) uzrokovat će i kondenzaciju protuiona koja će djelomično kompenzirati nepovoljna međudjelovanja na lancu i na taj način utjecati na disocijaciju polikiseline. Pri kvantitativnoj obradi protonacijske ravnoteže pored nepovoljnih interakcija na lancu stoga treba uzeti u obzir i kondenzaciju protuiona. Pritom je, s obzirom na iznimnu složenost problema adekvatnog obračuna svih doprinosa Gibbsovoj energiji sustava, nužno primjenjivati određene aproksimacije. Većina njih temelji se na pojednostavljenim modelima polielektrolita i otapala i polazi od eksperimentalne činjenice da su upravo elektrostatske interakcije između suprotno nabijenih skupina najvažnije za odstupanje prividnih od intrinzičke konstante deprotonacije. ${ }^{1,2}$ Stoga se kod obrade protonacijske ravnoteže homoplikiselina visoke gustoće naboja redovito nastoji procijeniti reverzibilni, nevolumni, električni rad koji je potrebno uložiti za povećanje naboja na poliionu u atmosferi protuiona. ${ }^{2}$ Spomenuti elektrostatski doprinos Gibbsovoj energiji $\left(G_{\mathrm{e}}\right)$ i intrinzički (kemijski) doprinos Gibbsovoj energiji $\left(G_{c}\right)$ smatraju se aditivnim, stoga njihov zbroj definira položaj ravnoteže u sustavu. ${ }^{2}$ Infinitezimalni prirast Gibbsove energije s obzirom na doseg

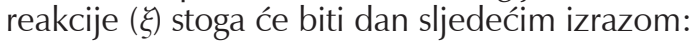

$$
\frac{d G}{d \xi}=\frac{d G_{c}}{d \xi}+\frac{d G_{e}}{d \xi}
$$

Pri nekom stupnju disocijacije monomera $\frac{d G_{c}}{d \xi}$ jednak je: ${ }^{2}$

$$
\frac{\mathrm{d} G_{\mathrm{c}}}{\mathrm{d} \xi}=\sum_{i} v_{i} \mu_{i}^{\ominus}+R T \ln \prod_{i}\left(\frac{[c]_{i}}{c^{\ominus}}\right)
$$

gdje $[c]_{i}$ označava ravnotežnu koncentraciju $i$-te kemijske vrste koja sudjeluje u procesu, $\mu_{i}^{\ominus}$ pripadni standardni kemijski potencijal, a $c^{\ominus}$ standardnu koncentraciju.

Za određivanje elektrostatskog doprinosa Gibbsovoj energiji u prvoj aproksimaciji površini poliiona pridružuje se prosječan površinski potencijal, $\psi_{0}:{ }^{2,22-24}$

$$
\psi_{0}=\frac{\mathrm{d} G_{\mathrm{e}}}{\mathrm{d} Q_{p}}
$$

u kojemu je s $Q_{p}$ označen naboj poliiona. Uz navedeno približenje, elektrostatski doprinos Gibbsovoj energiji prilikom protonacije (deprotonacije) podrazumijeva prijenos protona iz otopine s potencijala $\phi$, koji je posljedica prosječne raspodjele iona oko $\mathrm{H}^{+}(\mathrm{aq})$, na polimerni lanac gdje će biti pod utjecajem potencijala $\psi_{0}{ }^{2} \mathrm{U}$ slučaju pozitivno nabijene polikiseline infinitezimalna promjena naboja na polionu zbog protonacije iznosi:

$$
\begin{aligned}
\mathrm{d} Q & =\mathrm{d}\left(N_{\mathrm{HA}^{+}} \mathrm{e}\right)=\mathrm{e} L \mathrm{~d}\left[-\mathrm{HA}^{+}\right] V= \\
& =F \mathrm{~d}\left(c_{\mathrm{m}}-[-\mathrm{A}] V\right)=-F \mathrm{~d} \xi
\end{aligned}
$$

gdje je s e označen elementarni naboj, s L Avogadrova, a s $F$ Faradeyeva konstanta.

Kombiniranjem jednadžbi (8)-(10) proizlazi:

$$
\begin{gathered}
\frac{d G_{\mathrm{c}}}{\mathrm{d} \xi}+\frac{\mathrm{d} G_{\mathrm{e}}}{\mathrm{d} \xi}= \\
=\sum_{i} v_{i} \mu_{i}^{\ominus}+R T \ln \prod_{i}\left(\frac{[C]_{i}}{C^{\ominus}}\right)^{v_{i}}+R T \ln \gamma_{\mathrm{H}^{+}}-F \psi_{0}
\end{gathered}
$$

gdje je $\mathrm{s} \gamma_{\mathrm{H}^{+}}$Označen koeficijent aktiviteta protona $\mathrm{u}$ otopini. Prethodni izraz često se modificira uvođenjem takozvane intrinzičke konstante ravnoteže deprotonacije $K_{\text {in }}{ }^{\ominus}$ :

$$
\mathrm{p} K_{\text {in }}^{\ominus}=\frac{\sum_{i} \mu_{i}^{\ominus} v_{i}}{R T \ln 10}
$$

i miješane, prividne konstante deprotonacije (6). Ako se parcijalna derivacija Gibbsove energije po dosegu izjednači s nulom (kemijska ravnoteža), standardna intrinzička konstanta ravnoteže i prividne konstante ravnoteže bit će povezane sljedećim izrazom: ${ }^{22-24}$

$$
K_{\text {in }}^{\ominus}=K_{\text {ap }}^{*}(\alpha) \cdot \exp \left[-\frac{F \psi_{0}}{R T}\right]
$$


Valja reći da su jednadžbu (8), na kojoj počiva obrada protonacijske ravnoteže polikiselina, prvi predložili Debyeu i Hückel ${ }^{21}$ za opis ionskih interakcija u otopinama elektrolita, odnosno za uvođenje elektrokemijskog potencijala (koeficijenta aktiviteta nabijenih vrsta). Prema jednadžbi (13) koeficijenti aktiviteta protona na pozitivno nabijenom polimernom lancu bit će jednaki:

$$
\gamma_{-\mathrm{AH}^{+}}=\exp \left(\frac{-F \psi_{0}}{R T}\right)
$$

Opis protonacijske ravnoteže homopolikiselina visoke gustoće naboja pomoću izraza (13) prvi su predložili Overbeek i Arnold. ${ }^{22,23}$ Za procjenu $\psi_{0}$ pretpostavili su da proton disocira iz unutrašnjosti domene poliiona, koja se može smatrati sferom s uniformno raspoređenim, nabijenim segmentima. U slučaju polikiselina čiju su protonaciju istražili (poliakrilna kiselina, polimetakrilna kiselina), ${ }^{22,23}$ slaganje predloženog modela s eksperimentalnim podatcima bilo je tek $\mathrm{u}$ ispravnom trendu ovisnosti $\mathrm{p} K_{\mathrm{ap}}(\alpha)$. Protonacijsku ravnotežu homopolikiselina pomoću izraza (13) nastojali su uz pretpostavku sferne geometrije poliiona opisati i Katchalsky i sur. ${ }^{24}$ Pritom su pretpostavili da proton disocira s površine uniformno nabijene sfere te da je površinski potencijal jednak elektrokinetičkom potencijalu poliiona. Međutim niti navedeni način obrade podataka nije rezultirao dobrim slaganjem s eksperimentalnim podatcima.

Na neprikladnost pretpostavke o sfernoj geometriji polikiselina kod obrade protonacijske ravnoteže prvi je ukazao Nagasawa, ${ }^{25,26}$ istaknuvši da će se zbog velike gustoće naboja na lancu i tek djelomične kompenzacije naboja protuionima nabijene funkcijske skupine na poliionu nastojati u prostoru rasporediti tako da njihova međusobna udaljenosti bude što veća. ${ }^{25}$ Posljedično, navodi da će za opis odstupanja $\mathrm{p} K_{\mathrm{ap}}(\alpha)-\mathrm{p} K_{\mathrm{in}}^{\ominus}$ za većinu polielektrolita biti prikladnije približenje cilindrične geometrije poliiona. Nagasawa i suradnici ${ }^{26,27}$ su prilikom obrade podataka pretpostavili da protoni disociraju s površine beskonačno dugog, homogeno nabijenog cilindra polumjera $b$ na kojemu se nabijene skupine nalaze na udaljenosti I. Površinska gustoća naboja $\left(\sigma_{0}\right)$ takvog modela poliiona određena je stupnjem disocijacije svih monomera u sustavu prema jednadžbi:

$$
\sigma_{0}=\frac{e(1-\alpha)}{2 \pi b l}=\frac{e \theta}{2 \pi b l}
$$

gdje je sa $\theta$ označen stupanj protonacije homopolikiseline koja je u nedisociranoj formi pozitivno nabijena. U slučaju kada su protonirane skupine na polikiselini neutralne, stupanj protonacije u izrazu (15) valja zamijeniti stupnjem disocijacije. Pritom treba naglasiti da za opis protonacije predloženim modelom, ukoliko je polumjer zakrivljenosti poliiona dovoljno velik, geometrija cijelog poliiona ne mora nužno biti cilindrična. ${ }^{25}$ Također, iako poliion ima konačnu duljinu, aproksimacija strukture nabijenog lanca beskonačnim cilindrom može se smatrati prikladnom u slučaju kada se poliion sastoji od dovoljno velikog broja povezanih monomera.

Nagasawa i sur. ${ }^{26,27}$ su za račun površinskog potencija- la pomoću opisanog modela polliona primijenili rješenja Poisson-Boltzmannove (PB) jednadžbe za cilindričnu geometriju nabijenog objekta koje za otopinu jednostavnog, binarnog elektrolita glasi:

$$
\frac{1}{r} \frac{\mathrm{d}}{\mathrm{d} r}\left(r \frac{\mathrm{d} \psi}{\mathrm{d} r}\right)=\frac{\kappa^{2}}{2 k T e}\left[\exp \left(\frac{\mathrm{e} \psi}{k T}\right)-\exp \left(\frac{-\mathrm{e} \psi}{k T}\right)\right]
$$

U prethodnom izrazu oznakom $\kappa$ označena je recipročna Debyeova duljina:

$$
\frac{1}{\kappa}=\left(\frac{\varepsilon_{0} \varepsilon_{r} k T}{\left(\sum_{i} z_{i} e\right)^{2} C_{i 0}}\right)^{\frac{1}{2}}
$$

a s $C_{i 0}$ analitička koncentracija ionske vrste $i$ nabojnog broja $z_{i}$. Oznakama $\varepsilon_{0}$, odnosno $\varepsilon_{r}$ označene su permitivnost vakuuma i relativna permitivnost medija. Rješenje jednadžbe (16) u Debye-Hückelovoj aproksimaciji sljedeća je funkcija udaljenosti od poliiona:1,2,25

$$
\psi(r)=\frac{e \theta}{2 \pi \varepsilon_{0} \varepsilon_{r} l} \frac{K_{0}(\kappa r)}{\kappa r K_{1}(\kappa r)}
$$

gdje su s $K_{n}(r)$ označene modificirane Besselove funkcije druge vrste. 1,2,25,27 Kako prema pretpostavci protoni disociraju s površine poliiona, za račun $\psi_{0}$ potrebno je uzeti u obzir i najmanju udaljenost središta protuiona od površine, koja je jednaka polumjeru protuiona (a). ${ }^{25}$ Površinski potencijal na poliionu polumjera $b$ stoga je dan jednadžbom:

$$
\psi_{0}=\frac{\mathrm{e} \theta}{2 \pi \varepsilon_{0} \varepsilon_{r} l}\left[\frac{K_{0}(\kappa \mathrm{a})}{\kappa a K_{1}(\kappa a)}+\ln \left(\frac{\mathrm{a}}{b}\right)\right]
$$

Član $\frac{e \theta}{2 \pi \varepsilon_{0} \varepsilon_{r} l} \ln \left(\frac{a}{b}\right)$ u izrazu (19) jednak je razlici površin-

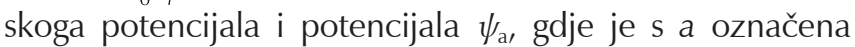
najmanja udaljenost središta mase protuiona od površine poliiona. Kao što je vidljivo, jednadžba (19) predviđa linearnu ovisnost $\psi_{0}$ o $\theta$. Prema izrazu (13) i ovisnost $\mathrm{p}_{\mathrm{ap}}{ }^{*}(\theta)$, odnosno $\alpha$, u slučaju kada su protonirani monomeri neutralni, trebala bi biti linearna.

Istraživanjem protonacijske ravnoteže poli(akrilne kiseline) u vodenim otopinama $\mathrm{NaCl}$ različitih koncentracija $\mathrm{Na}$ gasawa $i$ sur. ${ }^{26,27}$ pokazali su da je ovisnost $\mathrm{p} K_{\text {ap }} \mathrm{o} \alpha$ bila tek približno linearna, posebice pri niskim koncentracijama elektrolita. Spomenuti autori znatno su bolje slaganje eksperimentalnih podataka i predloženoga modela dobili numeričkim rješavanjem Poisson-Boltzmannove jednadžbe. Navedenu činjenicu pojasnili su neprikladnošću Debye-Hückelove aproksimacije za poliion velike gustoće naboja. ${ }^{26}$ Treba spomenuti da su navedeni istraživači prilikom obrade podataka kao standardnu intrinzičku konstantu poli(akrilne kiseline) upotrebljavali $K_{\text {in }}{ }^{\ominus}$ akrilne kiseline. 
Kasnija istraživanja pokazala su da primijenjena aproksimacija u slučaju nekih polikiselina nije zadovoljavajuća. ${ }^{28} \mathrm{Op}$ ćenito, određivanju $K_{\text {in }}{ }^{\ominus}$ monomera u literaturi posvećeno je nedovoljno pažnje, iako obrada protonacijske ravnoteže podrazumijeva (jednadžba (13)) poznavanje njezine točne vrijednosti. Nerijetko se vrijednosti koncentracijskih konstanti ravnoteže na $\alpha=0$ proglašavaju standardnim intrinzičkim konstantama protonacije polikiselina čiji su protonirani monomeri neutralni ${ }^{20,32}$ premda bi navedene veličine trebale ovisiti o ionskoj jakosti (jednadžba (6)). Kako je već bilo govora, koncentracijske konstante protonacije pozitivno nabijenih kiselina pri $\alpha=0$ trebale bi biti neovisne o $I_{C} \mathrm{i}$ po vrijednosti bliske $K_{\text {in }}{ }^{\ominus}$. Novija istraživanja pokazala su da je u slučaju poli(alilamonijeva) kationa tomu zaista tako, ${ }^{28}$ međutim, za donošenje općeg zaključka nužna su daljnja istraživanja. Drugi je česti problem kvantitativnog opisa protonacijske ravnoteže određivanje specijacije u otopini na osnovi izmjerenih pH-vrijednosti. Naime, elektrokemijski članci često se baždare pomoću standardnih pufera, a određeni se aktivitet izjednačava s koncentracijom $\mathrm{H}^{+} \mathrm{u}$ otopini, čak i pri vrlo velikim ionskim jakostima. U mnogim radovima baždarenje članaka nije niti opisano. Za ispravno potenciometrijsko određivanje stupnja disocijacije polikiselina velike gustoće naboja ravnoteže najčešće je potrebno baždariti članak na koncentracijskoj skali uz održavanje stalne ionske jakosti u otopini. Alternativno rješenje jest baždariti članak pomoću standardnih pufera, ${ }^{18}$ a zatim primijeniti Irvingovu metodu, ${ }^{29}$ za prijelaz na koncentracijsku, p[H] skalu. Dakako, uvijek ostaje pitanje određivanja relativnog aktiviteta $\mathrm{H}^{+}$. Za određivanje spomenute veličine najčešće se rabi puferska skala, ${ }^{28}$ a ponekad, pri nižim ionskim jakostima, i Debye-Hückelov model. ${ }^{26,27}$

Izračun površinskog potencijala, bilo prema jednadžbi (19), bilo numeričkim rješavanjem Poisson-Boltzmannove jednadžbe, pretpostavlja da jednadžba zadovoljavajuće opisuje ovisnost $\psi$ o $r$ sve do udaljenosti središta protuiona od površine. Istraživanja protonacije polikiselina, ${ }^{28,32}$ ali i površinskog naboja koloidnih čestica, ${ }^{31,31}$ ukazala su da pri višim ionskim jakostima to često nije slučaj. Također, spomenuta jednadžba ne ostavlja mogućnosti za obračun utjecaja različitih protuiona na vrijednost $\psi_{0}$, osim kroz varijaciju polumjera iona a (nespecifična, elektrostatska kondenzacija iona). Spomenuta ograničenja cilindričnog PB-modela za opis protonacijske ravnoteže polikiselina mogu se donekle izbjeći modificiranjem ovisnosti potecijala od neke udaljenosti a do površine poliiona (slika 1) takozvanim Sternovim modelom. ${ }^{1,2,28-33}$ Naime, Poisson-Boltzmannova jednadžba dobro će opisivati ovisnost električnog potencijala na većim udaljenostima od protuiona, sve do početka takozvanog difuznog dijela ionske atmosfere. U unutrašnjem, Sternovu sloju, pretpostavlja se linearna ovisnost potencijala o udaljenosti od površine. Potencijal na početku difuznog dijela atmosfere moguće je stoga povezati s površinskom gustoćom naboja sljedećom jednadžbom:

$$
\psi_{0}-\psi_{d}=\frac{-\sigma_{0}}{\varepsilon_{r} \varepsilon_{0}} d
$$

gdje je $d$ debljina Sternova sloja, a $\sigma_{0}$ površinska gustoća naboja na cilindričnom modelu poliiona.
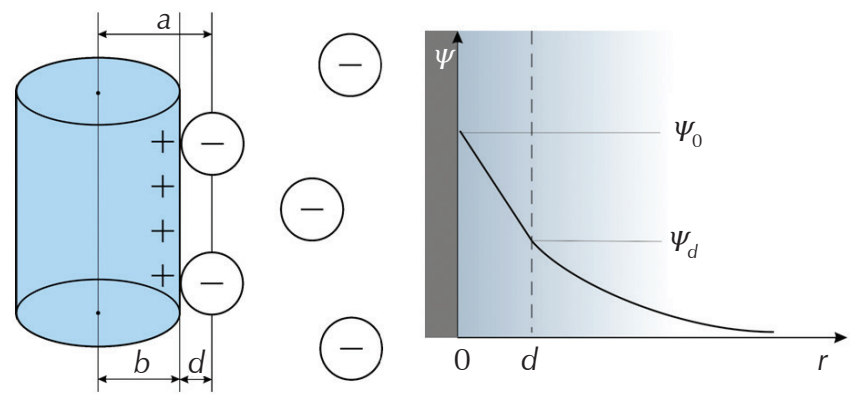

Slika 1 - Shematski prikaz Sternova modela u cilindričnoj geometriji ( $b$ - polumjer cilindra, $d$ - debljina Sternova sloja, $\psi_{0}-$ površinski potencijal, $\psi_{\mathrm{d}}$ - potencijal plohe na početku difuznog dijela ionske atmosfere)

Fig. 1 - Schematic representation of the cylindrical Stern model $\left(b-\right.$ cylinder radius, $d$ - thickness of Stern layer, $\psi_{0}$ - surface potential, $\psi_{\mathrm{d}}$ - potential at the onset of the diffuse part of the ionic atmosphere)

Primjeri primjene Sternova modela za opis protonacijske ravnoteže linearnih homopolikiselna iznimno su malobrojni. ${ }^{28,32} U$ slučaju poli(akrilne kiseline) ${ }^{32}$ u vodenim otopinama soli alkalijskih kationa slaganje modela s eksperimentalno određenim prividnim $\mathrm{pK}$-vrijednostima bilo je zadovoljavajuće, međutim, debljina Sternova sloja bila je bitno veća od kristalografskih polumjera kationa. Suprotno, u slučaju poli(alilamina) ${ }^{28}$ zamijećeno je nešto lošije slaganje izračunatih i eksperimentalnih $\mathrm{p} K_{\mathrm{ap}}{ }^{*}$, ali su debljine Sternova sloja bile usporedive s dimenzijama protuaniona $\left(\mathrm{Cl}^{-}, \mathrm{Br}^{-}, \mathrm{I}^{-}, \mathrm{NO}_{3}^{-}\right)$. Treba reći da u publikaciji Sadeghpour i sur. ${ }^{32}$ baždarenje članka nije opisano. Spomenuti autori također su prilikom obrade podataka pri ispitanim ionskim jakostima primjenjivali koncentracijske intrinzičke vrijednosti $\mathrm{pK}$, a ne odgovarajuću standardnu vrijednost (jednadžba (13)). Zanimljivo, u slučaju oba poliiona ${ }^{28,32}$ ovisnost prividnih konstanti ravnoteže o vrsti protuiona bila je relativno blaga premda su hidratacijski termodinamički parametri istraživanih protuiona bitno drugačiji. ${ }^{34}$ Navedena činjenica ukazuje na pretežno elektrostatsko vezivanje protuiona, odnosno slično zasjenjenje nabijenih skupina svim istraživanim protuionima. Naime, udjel izravno vezanih, desolvatiranih protuiona može, i najvjerojatnije jest, drugačiji. ${ }^{35}$ Očekivano, utjecaj vrste protuiona na $\mathrm{p} K_{\mathrm{ap}}{ }^{*}$ mogao se zamijetiti samo pri velikim gustoćama naboja poliiona. ${ }^{28,32}$ Suprotno, koncentracija elektrolita izrazito je utjecala na iznos prividnih konstanti ravnoteže protonacije poli(akrilne kiseline) ${ }^{32}$ i poli(alilamina). ${ }^{28}$

Glavni nedostatci obrade protonacijske ravnoteže cilindričnim Sternovim modelom temeljenim na Poisson-Boltzmannovoj jednadžbi, odnosno cilindričnim PB modelom, jesu zamjena diskretne raspodjele naboja na poluionu kontinuiranom, odnosno zanemarivanje strukture poliiona, protuiona te otapala. Ova gruba aproksimacija postaje upitna pri velikim gustoćama naboja poliona, kada dolazi do stvaranja ionskih parova između nabijenih skupina na lancu i protuiona (djelomična ili potpuna desolvatacija nabijenih vrsta). Također, promjenom stupnja disocijacije može se mijenjati i konformacija polielektrolita. Promjene konformacije mogu uzrokovati i promjene u solvataciji nabijenih i nenabijenih funkcijskih skupina, a stoga i u afi- 
nitetu prema protonu, što u okviru navedenih modela nije uzeto u obzir. Zadovoljavajuće slaganje eksperimentalnih i protonacijskih parametara polikiselina visoke gustoće naboja izračunatih temeljem prethodno opisanih modela ${ }^{26-28,32}$ stoga pomalo i iznenađuje.

Pored opisanog načina obrade protonske ravnoteže linearnih polikiselina nerijetko se primjenjuju i semiempirijske jednadžbe poput jednadžbe Katchalskog, ${ }^{36}$ Högfeldta, ${ }^{37-39}$ odnosno Mandela. ${ }^{20}$ Katchalsky za ovisnost prividnih, koncentracijskih konstanti ravnoteže protonacije predlaže sljedeći izraz: ${ }^{36}$

$$
\mathrm{p} K_{\mathrm{ap}}=\mathrm{p} K_{\mathrm{in}}+(n-1) \log \frac{\theta}{1-\theta}
$$

u kojemu je s n označen empirijski parametar koji se može odrediti regresijskom analizom eksperimentalnih podataka. Semiempirijske relacije prema Högfeldtu i Mandelu predviđaju da se ovisnost prividnih konstanti ravnoteže o stupnju disocijacije može aproksimirati polinomom drugoga stupnja. Primjerice, za linearne homopolikiseline Mandel predlaže sljedeću relaciju:20

$$
\mathrm{p} K_{\mathrm{ap}}=\mathrm{p} K_{\mathrm{in}}+\phi_{1} \theta+\phi_{2} \theta^{2}
$$

gdje su $\phi_{1}$ i $\phi_{2}$ empirijski koeficijenti koji se određuju regresijskom analizom eksperimentalnih podataka prema danoj jednadžbi. Högfeldt ${ }^{37}$ navodi da se ovisnost prividnih konstanti ravnoteže o stupnju disocijacije može opisati jednadžbom:

$$
\log K_{\alpha}^{\mathrm{H}}=(1-\theta)^{2} \log K_{1}^{\mathrm{H}}+\theta^{2} \log K_{0}^{\mathrm{H}}+2 \theta(1-\theta) \log K_{\mathrm{m}}^{\mathrm{H}}
$$

pri čemu su parametri koji se procjenjuju prividna konstanta deprotonacije pri $\alpha=0,5\left(\mathrm{~K}^{\mathrm{H}}\right)$ te intrinzička konstanta deprotonacije $\left(K^{H}\right)$ i prividna konstanta ravnoteže deprotonacije kada je polielektrolit u potpunosti nabijen $\left(K^{\mathrm{H}}\right)$. Izraz (23) pretpostavlja da se struktura polielektrolita može predstaviti trima regijama: jednom koja sadržava samo deprotonirani oblik, jednom koja sadržava protonirani oblik i regijom koja sadržava oba oblika. Udjel navedenih regija može se smatrati proporcionalnim ukupnom broju parova neprotoniranih skupina, ukupnom broju parova protoniranih skupina te ukupnom broju parova protoniranih i neprotoniranih skupina. Prema Guggenheimovoj nultoj aproksimaciji za regularne smjese ${ }^{40}$ moguće je pokazati da će uz navedene pretpostavke ovisnost prividnih konstanti ravnoteže biti dana jednadžbom (23). Međutim, valja reći da primijenjena približenja predstavljaju zaista gruba pojednostavljena protonacijske ravnoteže na poliionu. Nadalje, niti Högfeldt niti autori koji primjenjuju navedenu jednadžbu ${ }^{41,42}$ ne specificiraju je li riječ o miješanim ili koncentracijskim prividnim konstantama ravnoteže. Unatoč nedostatcima, jednadžbe Högfeldta i Mandela pokazale su se iznimno korisnim za opis ovisnosti prividnih, koncentracijskih i miješanih konstanti ravnoteže protonacije polikiselina o stupnju disocijacije, ${ }^{28,41,42}$ posebice za određivanje $\mathrm{p} K_{\mathrm{in}}{ }^{\ominus}, 8$ nužne za obradu eksperimentalnih podataka složenijim modelima (Sternov cilindrični model temeljen na PB-teoriji, odnosno PB cilindrični model).
U slučaju kada je udaljenost između nabijenih skupina na poliionu izrazito mala, procjena električkog doprinosa Gibbsovoj energiji pomoću prosječnog površinskog potencijala više neće vrijediti. ${ }^{1,2}$ Primjerice, protonacijsku ravnotežu linearnog poli(etilenimina) ${ }^{43}$ u kojemu su dušikovi atomi integrirani u lanac i odvojeni sa svega dva ugljikova atoma, zatim poli(maleinska kiselina) ${ }^{44,45}$ i poli(fumarna kiselina $)^{44}$ u kojima se karboksilne skupine nalaze na susjednim ugljikovim atomima u lancu neće biti moguće opisati jednadžbom (13). Za spomenute kiseline $\mathrm{p} K_{\mathrm{ap}}(\alpha)$ više nije približno linearna, kao u slučaju polikiselina kod kojih se funkcijske skupine nalaze na svakom drugom ugljikovom atomu, ${ }^{20-28,32}$ već sigmoidalna s točkom infleksije pri $\alpha=0,5 \cdot 43-45$

Kod navedenog tipa molekula dominantan doprinos elektrostatskoj energiji na poliionu predstavlja odbijanje između dviju susjednih skupina koje se nalaze na udaljenosti $I$. Zanemare li se svi ostali doprinosi (primjerice interakcije triju, ili četiriju nabijenih skupina), ovisnost prividnih konstanti ravnoteže o stupnju deprotonacije može se opisati Isingovim ${ }^{1,2,43,45}$ modelom u kojemu je razlikama u intrinzičkoj i prividnim $\mathrm{pK}$-vrijednostima $\left(\Delta \mathrm{p} K_{\mathrm{ap}}\right)$ koje predviđa jednadžba (13) dodan član koji uzima u obzir odbojne interakcije između susjednih monomera. Prema spomenutom modelu intrinzička konstanta deprotonacije monomera bit će dana jednadžbom:

$$
\begin{gathered}
\mathrm{p} K_{\text {in }}=\Delta \mathrm{p} K_{\text {ap }}+\frac{2(\alpha-1) w}{k T \ln 10}+ \\
+\log \left(\frac{\left[2 \alpha-1+\sqrt{4 \alpha(1-\alpha)\left(\mathrm{e}^{\frac{-w}{k T}}-1\right)+1}\right](1-\alpha)}{\left[-2 \alpha+1+\sqrt{4 \alpha(1-\alpha)\left(\mathrm{e}^{\frac{-w}{k T}}-1\right)+1}\right] \alpha}\right)
\end{gathered}
$$

gdje je $s w$ označena potencijalna energija dvaju nabijenih elementarnih naboja na udaljenosti / zasjenjena ionskom atmosferom:

$$
w=\frac{\mathrm{e}^{2}}{4 \pi \varepsilon_{0} \varepsilon_{r} l} \frac{\exp (-\kappa l)}{1+\kappa l}
$$

Izraz (25) pretpostavlja da je raspodjela protuiona oko dvije nabijene skupine definirana Debye-Hückelovim modelom (linearna PB jednadžba za sfernu geometriju centralnog iona ${ }^{2,12}$ ). Kako se može zaključiti, pored svih ograničenja vezanih uz određivanje $\Delta \mathrm{p} K_{\text {ap }}$ cilindričnim PB modelom, kod opisa interakcija između susjednih nabijenih skupina izrazom (25) struktura poliiona i struktura protuiona nije uzeta u obzir. Unatoč ograničenjima Isingova modela, slaganje izračunatih i eksperimentalnih protonacijskih parametara za poli(maleinsku kiselinu) ${ }^{4}$ i te linearni poli(etilenimin) ${ }^{43}$ iznimno je zadovoljavajuće u širokom području stupnja disocijacije. Odstupanja se javljaju tek pri vrlo visokoj gustoći naboja ( $\alpha \longrightarrow 1$ (poli(maleinska kiselina) odnosno $\alpha \rightarrow 0$ poli(etilenimin)). Valja napomenuti da $\mathrm{p} K_{\text {ap }}$ poli(fumarne kiseline) pri velikim vrijednostima stupnja disocijacije pokazuju znatnu ovisnost o vrsti alkalijskog kationa koji 
kompenzira naboj poliiona. ${ }^{44}$ Navedena činjenica najvjerojatnije je posljedica većeg udjela izravno vezanih, desoIvatiranih protuiona u odnosu na polikiseline niže gustoće naboja (poli(akrilna kiselina) i poli(alilamonijev) kation).

U novije vrijeme sve su češći opisi protonacijske ravnoteže linearnih homopolikiselina pomoću rezultata Monte Carlo (M. C.) simulacija. ${ }^{2,46,47}$ I u spomenutom opisu primjenjuju se razmjerno jednostavni modeli poliiona (kruti cilindrični model s kontinuiranom raspodjelom naboja, kruti cilindrični model s diskretnom raspodjelom naboja, fleksibilni model s diskretno raspoređenim nabijenim skupinama). Simulacije se izvode prema jednadžbi (13). Kemijski potencijal protona u otopini drži se konstantnim, a stupanj protonacije na poliionu se varira. U slučaju kada je zbroj kemijskog i elektrostatskog doprinosa Gibbsovoj energiji negativan, rezultat simulacije se prihvaća. Iz svih dobivenih, negativnih $\frac{d G_{c}}{d \xi}+\frac{d G_{e}}{d \xi}$ vrijednosti potom se računa prosječni stupanj disocijacije monomera, odnosno $\Delta \mathrm{p} K_{\mathrm{a}}$ p $(\alpha)$ pri određenoj vrijednosti pH. Istraživanja su pokazala da je slaganje između modelom izračunatih (fleksibilni poliion s diskretno raspoređenim nabijenim skupinama) i eksperimentalnih podataka za poli(akrilnu kiselinu) znatno bolje nego li slaganje između eksperimentanih i $\Delta \mathrm{p} K_{\mathrm{ap}}(\alpha)$ vrijednosti izračunatih temeljem krutog cilindričnog modela. ${ }^{47}$ Štoviše, za opis utjecaja ionske atmosfere na elektrostatski doprinos Gibbsovoj energiji sustava dostatno je riješiti P.-B. jednadžbu u Debye-Hückelovoj aproksimaciji. Suprotno, pri istim je ionskim jakostima slaganje eksperimentalnih podataka i podataka izračunatih na temelju cilindričnog modela s kontinuiranom raspodjelom bilo zadovoljavajuće samo ako je P.-B. jednadžba bila riješena u nelinearnom obliku. Međutim, valja istaknuti da su modeli na kojima se simulacije temelje znatno pojednostavljeni. Naime, struktura skupine sudjeluje u protonacijskoj ravnoteži nije ni na koji način uzeta u obzir, a otapalo se redovito smatra dielektričnim kontinuumom.

\section{Zaključak}

Položaj ravnoteže (specijaciju) u otopinama homopolikiselina velike gustoće naboja definiraju kemijski doprinos Gibbsovoj energiji (kemijski potencijali sudionika reakcije), odnosno elektrostatski doprinos Gibbsovoj energiji sustava (doprinos Gibbsovoj energiji sustava zbog nepovoljnih djelovanja nabijenih skupina na lancu koje su zasjenjene atmosferom protuiona). Opis protonacijske ravnoteže polielektrolita različitim modelima stoga podrazumijeva procjenu elektrostatskog doprinosa Gibbsovoj energiji sustava uz poznati stupanj disocijacije monomera, odnosno poznatu standardnu intrinzičku konstantu ravnoteže deprotonacije.

Za procjenu $G_{e}$ još se uvijek najčešće primjenjuje primitivan cilindrični model poliiona $s$ kontinuiranom raspodjelom naboja. Pritom se redovito pretpostavlja da je raspodjela protuiona definirana Poisson-Boltzmannovom jednadžbom. Ukoliko se funkcijske skupine na poliionu nalaze na svakom drugom ugljikovu atomu, svakako valja izbjegavati rješenja P.-B. jednadžbe u linearnom obli- ku. Unatoč ograničenjima opisanog modela, slaganje je na opisani način izračunatih $p K_{a p} s$ eksperimentalnim vrijednostima u slučaju polikiselina pri nižim ionskim jakostima u binarnim $1: 1$ elektrolitima $\left(I_{c} \leq 0,1 \mathrm{~mol} \mathrm{dm}^{-3}\right)$ zadovoljavajuće. ${ }^{2,26,27}$ Međutim, treba reći da su udaljenosti između nabijenih skupina u modelu kod primjerice poli(akrilne kiseline) $(I=5,5 \AA)$ ipak veće od realnih.

Pri većim ionskim jakostima u slučaju polikiselina funkcionaliziranima na svakom drugom atomu u okosnici lanca potrebno je modificirati ovisnost potencijala u blizini poliiona uvođenjem Sternova sloja..$^{28,32}$ Naime, rješenja Poisson-Boltzmanove jednadžbe rezultiraju suviše visokim površinskim potencijalima. Kod linearnih polikiselina s funkcijskim skupinama na svakome ugljikovom atomu aproksimacija središnjeg polja više nije dovoljna za opis protonacijske ravnoteže, već je potrebno primjenjivati modele $s$ diskretnom raspodjelom naboja. ${ }^{1,2,43-45}$ Najčešće je dovoljno uzeti u obzir samo interakcije između susjednih nabijenih skupina (Isingov model), 1,2,43-45 za koje se pretpostavlja da su jednake potencijalnoj energiji dvaju nabijenih elementarnih naboja na udaljenosti I zasjenjenih ionskom atmosferom. Raspodjela protuiona oko nabijenih skupina pritom je redovito definirana Debye-Hückelovim modelom. Iznenađujuće, spomenutim je modelom moguće zadovoljavajuće opisati protonacijsku ravnotežu poli(maleinske kiseline) i poli(fumarne kiseline) pri nižim ionskim jakostima $\left(I_{c} \leq 0,1 \mathrm{~mol} \mathrm{dm}^{-3}\right) .{ }^{43-45}$

Sve su češći i opisi protonacijske ravnoteže homopolikiselina rezultatima Monte Carlo simulacija. ${ }^{2,46,47}$ Valja istaknuti da je adekvatan opis protonacijske ravnoteže pomoću M. C. simulacija dobiven i pomoću linearne Poisson-Boltzmannove jednadžbe u području ionskih jakosti u kojemu je primjenom krutog cilindričnog modela poliiona bilo nužno rješavanje P.-B. jednadžbe u nelinearnom obliku. ${ }^{46,47}$ Pored navedenih načina obrade protonacijske ravnoteže svakako treba spomenuti i semiempirijske modele Mandela, ${ }^{20} \mathrm{Kat}-$ chalskog ${ }^{24}$ i Högfeldta. ${ }^{37-39}$ Naime, osim ponekad izrazito dobrog slaganja izračunatih i eksperimentalno određenih prividnih konstanti deprotonacije, spomenuti načini obrade omogućuju procjenu intrinzičkih pK-vrijednosti.

\section{Popis simbola i kratica \\ List of symbols and abbreviations}

a $\quad$ - polumjer izravno vezanog protuiona

- radius of directly bound counterion

b - polumjer poliiona

- polyion radius

$[c]_{i}$ - ravnotežna koncentracija vrste $i$

- equilibrium concentration of the species $i$

F - Faradayeva konstanta

- Faraday constant

G - Gibbsova energija

- Gibbs energy

$G_{c} \quad$ kemijski doprinos Gibbsovoj energiji

- chemical contribution to the Gibbs energy of the system

$G_{\mathrm{e}}$ - elektrostatski doprinos Gibbsovoj energiji

- electrical contribution to the Gibbs energy of the system 
e - elementarni naboj

- elementary charge

k - Boltzmannova konstanta

- Boltzmann constant

K - koncentracijska konstanta

ravnoteže deprotonacije monomera

- equilibrium constant of monomer

deprotonation (concentration scale)

$K^{\ominus} \quad$ - standardna konstanta ravnoteže

deprotonacije monomera

- standard equilibrium constant of monomer deprotonation

$K_{\text {ap }}$ - prividna koncentracijska konstanta deprotonacije monomera

- apparent equilibrium constant of monomer deprotonation (concentration scale)

* - prividna miješana konstanta ravnoteže

$K_{\text {ap }}{ }^{*} \quad$ deprotonacije monomera

- apparent mixed equilibrium constant of monomer deprotonation

$K^{\mathrm{H}}$ - konstanta ravnoteže deprotonacije monomera (Högfeldtov model)

- equilibrium constant of monomer deprotonation (according to Högfeldt)

$K^{\ominus}$ - standardna, intrinzička konstanta

$K_{\text {in }}{ }^{\ominus} \quad$ ravnoteže deprotonacije monomera

- standard intrinsic equilibrium constant of monomer deprotonation

$K_{\text {in }}$ - koncentracijska intrinzička konstanta ravnoteže deprotonacije monomera

- intrinsic equilibrium constant of monomer deprotonation (concentration scale)

$K_{n}(r)$ - Besselova funkcija druge vrste

- Bessel function of the second kind

I - udaljenost između susjednih funkcijskih skupina poliiona

- distance between vicinal functional groups of the polyion

$r \quad$ - udaljenost od poliiona

- distance from the polyion

$R \quad$ - opća plinska konstanta

- universal gas constant

$T$ - termodinamička temperatura

- thermodynamic temperature

w - potencijalna energija dvaju susjednih, nabijenih skupina

- potential energy of two vicinal charged groups

$\alpha \quad$ - stupanj disocijacije

- dissociation degree

$\gamma_{i} \quad$ - koeficijent aktiviteta vrste $i$

- activity coefficient of the species $i$

$\varepsilon_{0} \quad$ - dielektrična konstanta za vakuum

- dielectric permittivity of vacuum

$\varepsilon_{r} \quad$ - relativna dielektrična konstanta medija

- relative dielectric permittivity of medium

$\theta \quad$ - stupanj protonacije

- protonation degree

$\kappa \quad$ - recipročna Debyeova duljina

- the inverse of the Debye screening length

- standardni kemijski potencijal vrste $i$

$\mu_{i}^{\ominus} \quad$ - standard chemical potential of the species $i$

$v_{i} \quad$ - stehiometrijski koeficijent vrste $i$

- stoichiometric coefficient of the species $i$

$\xi-$ doseg reakcije

- reaction extent $\psi_{0} \quad$ - površinski potencija

- surface potential

P.-B. jednadžba - Poisson-Boltzmannova jednadžba

- Poisson-Boltzmann equation

M. C. simulacije - Monte Carlo simulacije

- Monte Carlo simulations

\section{Literatura}

References

1. M. Cohen Stuart, R. de Vries, H. Lyklema, Fundamentals of Interface and Colloid Science, Elsevier, Amsterdam, 2005, 2. poglavlje.

2. M. Borkovec, B. Jönsson, G. J. M. Koper u E. Matijević, ur., Surface and Colloid Science, Vol. 16, Kluwer Academic / Plenum Press, New York 2001, str. 99-339.

3. H. Dautzenberg, W. Jaeger, J. Kötz, B. Phillip, Ch. Seidler, D. Stscherbina, Polyelectrolytes: Formation, Characterisation and Application, Hanser, München, 1994.

4. J. Ray, G. S. Manning u: T. Radeva, ur., Physical Chemistry of Polyelectrolytes, M. Dekker, New York, 2001, str. 111-129.

5. G. S. Manning, Limiting laws and counterion condensation in polyelectrolyte solutions. 1. colligative properties, J. Chem. Phys. 51 (1969) 924-933, http://dx.doi. org/10.1063/1.1672157.

6. H. Dautzenberg, u: T. Radeva, ur., Physical Chemistry of Polyelectrolytes, M. Dekker, New York, 2001., str. 743-793.

7. R. M. Fuoss, H. Sadek, Mutual Interaction of Polyelectrolytes, Science 110 (1949) 552-780, doi: http://dx.doi. org/10.1126/science.110.2865.552.

8. J. Papenhuijzen, G. J. Fleer, B. H. Bijsterbosch, Polyelectrolyte adsorption. I. A new lattice theory, J. Colloid Interface Sci. 104 (1985) 530-538, http://dx.doi.org/10.1051/ jphys:019880049060100100.

9. R. Denoyel, G. Durand, F. Lafuma, R. Audebert, Adsorption of cationic polyelectrolytes on to montmorillonite and silica: microcalorimetric study of their conformation, J. Colloid Interface Sci. 139 (1990) 281-290, doi: http://dx.doi. org/10.1016/0021-9797(90)90463-X.

10. G. Decher, J. D. Hong, Buildup of ultrathin multilayer films by a self- assembly process. 1 . Consecutive adsorption of anionic and cationic bipolar amphiphiles on charged surfaces, Macromol. Chem. Macromol. Symp. 46 (1991) 321-327, doi: http://dx.doi.org/10.1002/masy.19910460145.

11. V. G. Decher,u: G. Decher, J. Schlenoff, ur., Multilayer Thin Films, Wiley-VCH, Weinheim, 2003, str. 1-31.

12. J. B. Schlenoff, u: G. Decher, J. Schlenoff, ur., Multilayer Thin Films, Wiley-VCH, Weinheim, 2003, str. 99-133.

13. S. Schneider, P. J. Feilen, V. Slotty, D. Kampfner, S. Preuss, S. Berger, J. Beyer, R. Pommersheim, Multilayer Capsules - A Promising Microencapsulation System for Transplantation of Pancreatic-Islets, Biomaterials 22 (2001) 1961-1970, doi: http://dx.doi.org/10.1016/S0142-9612(00)00380-X.

14. S. Y. Wong, Q. Li, J. Veselinovic, B. Kim, A. M. Klibanov, P. T. Hammond, Bactericidal and virucidal ultrathin films assembled layer by layer from polycationic N-alkylated polyethylenimines and polyanions, Biomaterials 31 (2010) 4079-4087, doi: http://dx.doi.org/10.1016/j.biomaterials.2010.01.119.

15. N. B. Thébaud, R. Bareille, R. Dalcusi, Ch. Rémy, H. Kerdjoudj, P. Menu, L. Borneave, Polyelectrolyte multilayer films allow seeded human progenitor-derived endothelial cells to 
remain functional under shear stress in vitro, Acta Biomater. 6 (2010) 1437-1445, doi: http://dx.doi.org/10.1016/j. actbio.2009.11.012

16. H. Möhwald, E. Donath, G. Sukhorukov, u: G. Decher, J. Schlenoff, ur., Multilayer Thin Films, Wiley- $\mathrm{VCH}$, Weinheim, 2003., str. 363-391.

17. D. Fiorentino, A. Gallone, D. Fiocco, G. Pallazo, A. Mallardi, Mushroom tyrosinase in polyelectrolyte multilayers as an optical biosensor for o-diphenols, Biosens. Bioelectron. 25 (2010) 2033-2037, doi: http://dx.doi.org/10.1016/j. bios.2010.01.033.

18. R. G. Bates, E. A. Guggenheim, Report on the standardization of $\mathrm{pH}$ and related terminology, Pure Appl. Chem. 1 (1960) 163-168, http://dx.doi.org/10.1351/pac196001010163.

19. F. J. C. Roscotti, H. Rossotti, The Determination of Stability Constants and Other Equilibrium Constants in Solution, McGraw-Hill Book Company, Inc., London, 1961., str. 1757.

20. M. Mandel, The potentiometric titration of weak polyacids, European Polym. J. 6 (1970) 807-822, doi: http://dx.doi. org/10.1016/0014-3057(70)90005-4.

21. P. Debye, E. Huckel, Zur Theorie der Elektrolyte. 1. Gefrierpunktserniedrigung ind verwandte Erscheinungen, Physikalische Zeitschrieft 24 (1923) 185-206.

22. J. Th. G. Overbeek, The Dissociation and Titration Constants of Polybasic Acids, Bull. Soc. Chim. Belg. 57 (1948) 252263, doi: http://dx.doi.org/10.1002/bscb.19480570416.

23. A. Arnold, J. Th. G. Overbeek, The dissociation and specific viscosity of polymethacrylic acid, Rec. Trav. Chim. 69 (1950) 192-206, doi: http://dx.doi.org/10.1002/ recl.19500690205.

24. A. Katchalsky, N. Shavit, H. Eisenberg, Dissociation of Weak Acids and Bases, J. Poym. Sci. 13 (1956) 69-84, doi: http:// dx.doi.org/10.1002/pol.1954.120136806.

25. M. Nagasawa, S. Rice, A Chain Model for Polyelectrolytes. V. A Study of the Effects of Local Charge Density, J. Am. Chem. Soc. 82 (1960) 5070-5076, doi: http://dx.doi.org/10.1021/ ja01504a016.

26. L. Kotin, M. Nagasawa, Potentiometric titration and ion binding in solution of linear polyelectrolytes, J. Chem. Phys. 36 (1962) 873-879, doi: http://dx.doi.org/10.1063/1.1732682.

27. M. Nagasawa, T. Murase, K. Kondo, Potentiometric Titration of Stereo- regular Polyelectrolytes, J. Phys. Chem. 69 (1965) 4005-4012, doi: http://dx.doi.org/10.1021/j100895a060.

28. K. Bohinc, D. Kovačević, J. Požar, Protonation equilibrium of the poly(allylammonium) cation in an aqueous solution of binary 1:1 electrolytes, Phys Chem Chem Phys. 15 (2013) 7210-7219, doi: http://dx.doi.org/10.1039/C3CP50302J.

29. H. M. Irving, M. G. Miles, L. D. Pettit, A study of some problems in determining the stoichiometric proton dissociation constants of complexes by potentiometric titrations using a glass electrode, Anal. Chim. Acta 38 (1967) 475-488, doi: http://dx.doi.org/10.1016/S0003-2670(01)80616-4.

30. I. Borukhov, D. Andelman, H. Orland, Steric Effects in Electrolytes: A Modified Poisson Boltzmann Equation, Phys. Rev. Lett. 79 (1997) 435, doi: http://dx.doi.org/10.1103/PhysRevLett.79.435.
31. K. Bohinc, V. Kralj-Iglič, A. Iglič, Thickness of electrical double layer. Effect of ion size, Electrochim. Acta 46 (2001) 3033, doi: http://dx.doi.org/10.1016/S0013-4686(01)00525-4.

32. A. Sadeghpour, A. Vaccaro, S. Rentsch, M. Borkovec, Influence of alkali metal counterions on the charging behavior of poly(acrylic acid), Polymer 50 (2009) 3950-3954, doi: http://dx.doi.org/10.1016/j.polymer.2009.06.032.

33. D. F. Evans, H. Wennerström, The Colloidal Domain, WileyVCH, New York, 1999, str. 103-152.

34. Y. Marcus, Ion Properties, M. Dekker, New York, 1997, str. 117-135.

35. U. P. Strauss, u: E. Selégny, ur., Polyelectrolytes. D. Reidel Publishing Company, 1974, str. 79-85.

36. A. Katchalsky, P. Spitnik, Potentiometric titrations of poly methacrylic acid, J. Polym. Sci. 2 (1947) 432-446, doi: http://dx.doi.org/10.1002/pol.1947.120020409.

37. E. Hoegfeldt, A useful method for summarizing data in ion exchange. 4. Extension and application to weak acid and chelating resins, J. Phys. Chem. 92 (1988) 6475-6476, doi: http://dx.doi.org/10.1021/j100333a057.

38. E. Hoegfeldt, T. Miyajima, J. A. Marinsky, M. Muhammed, Application of Simple Three-Parameter Model to Titration Data for Some Linear Polyelectrolytes, Acta Chim. Scand. 43 (1989) 496-499, doi: http://dx.doi.org/10.3891/acta.chem. scand.43-0496.

39. S. Alegret, E. Hoegfeldt, On Protonation of Sephadex C-25, Talanta 36 (1989) 873-874, doi: http://dx.doi. org/10.1016/0039-9140(89)80172-9.

40. E. A. Guggenheim, Mixtures, Clarendon Press, Oxford, 1952.

41. C. De Stefano, A. Gianguzza, J. Piazzese, S. Sammartano, Polyacrylates in aqueous solution. The dependence of protonation on molecular weight, ionic medium and ionic strength, React. Funct. Polym. 55 (2003) 9-20, doi: http://dx.doi. org/10.1016/S1381-5148(02)00194-3.

42. F. Crea, P. Crea, C. De Stefano, O. Giuffrè, A. Pettignano, S. Sammartano, Thermodynamic Parameters for the Protonation of Poly(allyamine) in concentrated $\mathrm{LiCl}_{(\mathrm{aq})}$ and $\mathrm{NaCl}_{(\mathrm{aq})}$ J. Chem. Eng. Data 49 (2004) 658-663, doi: http://dx.doi. org/10.1021/je0342264.

43. M. Borkovec, Ger J. M. Koper, C. Piguet, Ion binding to polyelectrolytes, Curr. Opin. Colloid Interface Sci. 11 (2006) 280289, doi: http://dx.doi.org/10.1016/j.cocis.2006.08.004.

44. T. Kitano, S. Kawaguchi, K. Ito, Dissociation Behavior of Poly(fumaric acid) and Poly(maleic acid). 1. Potentiometric Titration and Intrinsic Viscosity, Macromolecules 20 (1987) 1598-1606, doi: http://dx.doi.org/10.1021/ma00173a028.

45. J. de Groot, G. J. M. Koper, M. Borkovec, J. de Bleijser, Dissociation Behavior of Poly(maleic acid): Potentiometric Titrations, Viscosimetry, Pulsed Field Gradient NMR, and model calculations, Macromolecules 31 (1998) 4182-4188, doi: http://dx.doi.org/10.1021/ma971768f.

46. M. Ullner, B. Jönsson, B. Söderberg, C. Peterson, A Monte Carlo Study of Titrating Polyelectrolytes, J. Chem. Phys. 104 (1996) 3048-3057, doi: http://dx.doi.org/10.1063/1.471071.

47. M. Ullner, B. Jönsson, A Monte Carlo Study of Titrating Polyelectrolytes in the Presence of Salt, Macromolecules 29 (1996) 6645-6655, doi: http://dx.doi.org/10.1021/ma960309w. 


\section{SUMMARY}

\section{Protonation Equilibrium of Linear Homopolyacids \\ Josip Požar}

The paper presents a short summary of investigations dealing with protonation equilibrium of linear homopolyacids, in particularly those of high charge density. Apart from the review of experimental results which can be found in the literature, a brief description of theoretical models used in processing the dependence of protonation constants on monomer dissociation degree and ionic strength is given (cylindrical model based on Poisson-Boltzmann equation, cylindrical Stern model, the models according to Ising, Högfeldt, Mandel and Katchalsky). The applicability of these models regarding the polyion charge density, electrolyte concentration and counterion type is discussed. The results of Monte Carlo simulations of protonation equilibrium are also briefly mentioned. In addition, frequently encountered errors connected with calibration of glass electrode and the related unreliability of determined protonation constants are pointed out.

\section{Keywords}

Polymer, polyelectrolyte, homopolyacid, protonation, counterions

Department of Chemistry

Review

Faculty of Natural Sciences

University of Zagreb

Received March 20, 2014

Horvatovac 102a

10000 Zagreb, Croatia

Accepted June 9, 2014 